\title{
The Sulugssut intrusive complex: a new Tertiary alkaline centre in East Greenland
}

\author{
C. K. Brooks, P. R. Dawes and N. J. Soper
}

\begin{abstract}
The Sulugssut intrusive complex, discovered in 1986, lies between the glaciers of K. J. V. Steenstrup Søndre Bræ and K. J. V. Steenstrup Nordre Bræ at $66^{\circ} 30^{\prime}$ N. It has an approximate diameter of $5 \mathrm{~km}$ and consists of dense dyke swarms and a plutonic core in which tinguaites and ijolites appear to predominate. It is of particular interest on three main counts: (1) it represents the most southerly in the line of Tertiary igneous centres which stretches over $1000 \mathrm{~km}$ to the north, (2) its petrographic character, although resembling the Gardiner intrusion to the north, is unique in East Greenland, and (3) it is located close to the coast confounding earlier ideas that highly undersaturated magmas occur only inland.
\end{abstract}

\section{Introduction}

An alkaline intrusive complex, composed of a dense dyke swarm and plutonic core, was discovered in July 1986 during helicopter-supported geological investigations in the northern part of the Ammassalik region. The complex was reconnoitred from the air, several landings were made and a number of samples, both from in situ outcrops and from moraine, were collected.

In this paper we describe the discovery and general geology of the complex, present a new map of the immediate area and report on the petrography and chemistry of both the dykes and plutonic rocks.

\section{Location and naming}

The new complex is situated on a rugged semi-nunatak that separates the snouts of two major glaciers, K. J. V. Steenstrup Nordre Bræ and K. J. V. Steenstrup Søndre Bræ (fig. 1). It is situated about $175 \mathrm{~km}$ northeast of Ammassalik at approximate position $66^{\circ} 30^{\prime} \mathrm{N}$ and $34^{\circ} 48^{\prime} \mathrm{W}$, and about $10 \mathrm{~km}$ from the outer coast. The igneous centre is named here the Sulugssut intrusive complex; a name derived from Sulugssûtip apusiâ that is the East Greenlandic dialect name for K. J. V. Steenstrup Søndre Bræ.

\section{Discovery and mapping}

The Sulugssut complex was discovered during regional mapping of the Precambrian crystalline terrain in the northern part of the Proterozoic mobile belt (see Dawes et al., this volume - Northern boundary). Coast- parallel undeformed, brown-weathering Tertiary dykes are common in coastal areas and were also sampled during this work. Attention was initially drawn to the igneous complex by the sighting of a dense swarm of north-east trending dykes, in which prominent grey dykes forming resistent ridges occur together with darkweathering varieties. This swarm occurs in the southeastern margin of the complex on the southern flanks of peak $1056 \mathrm{~m}$ (fig. 1).

This unusual dyke swarm prompted a landing that was effected several kilometers away (locality A, fig. 1). Here grey dykes were determined to be of alkaline character with nepheline being readily identified in hand specimen. Two days later three other localities were examined (localities B, C \& D) while a brief stop was made at locality E. Localities A, B \& D are landings at which observations were made and samples collected in the immediate area of the helicopter. At locality $\mathrm{C}$ one of us (CKB) made a half-day traverse across a dyke swarm. Only one locality (B) is situated on the plutonic core, localities $\mathrm{A}$ and $\mathrm{C}$ are on dyke swarms cutting the host Precambrian gneisses and localities D and $E$ are on moraine (fig. 1).

The map presented as fig. 1 has been prepared in GGU by photogrammetry (Olav Winding) and photogeological interpretation (PRD) using vertical aerial photographs at scale 1:150 000 (Geodætisk Institut, Copenhagen). The map was drawn out by digital plotter at the scale of 1:25000.

Due to extensive ice and snow cover the precise outcrop form of the complex is difficult to determine. In the north-east the boundary of the plutonic core seems generally well-defined and a sharp contact can be seen 


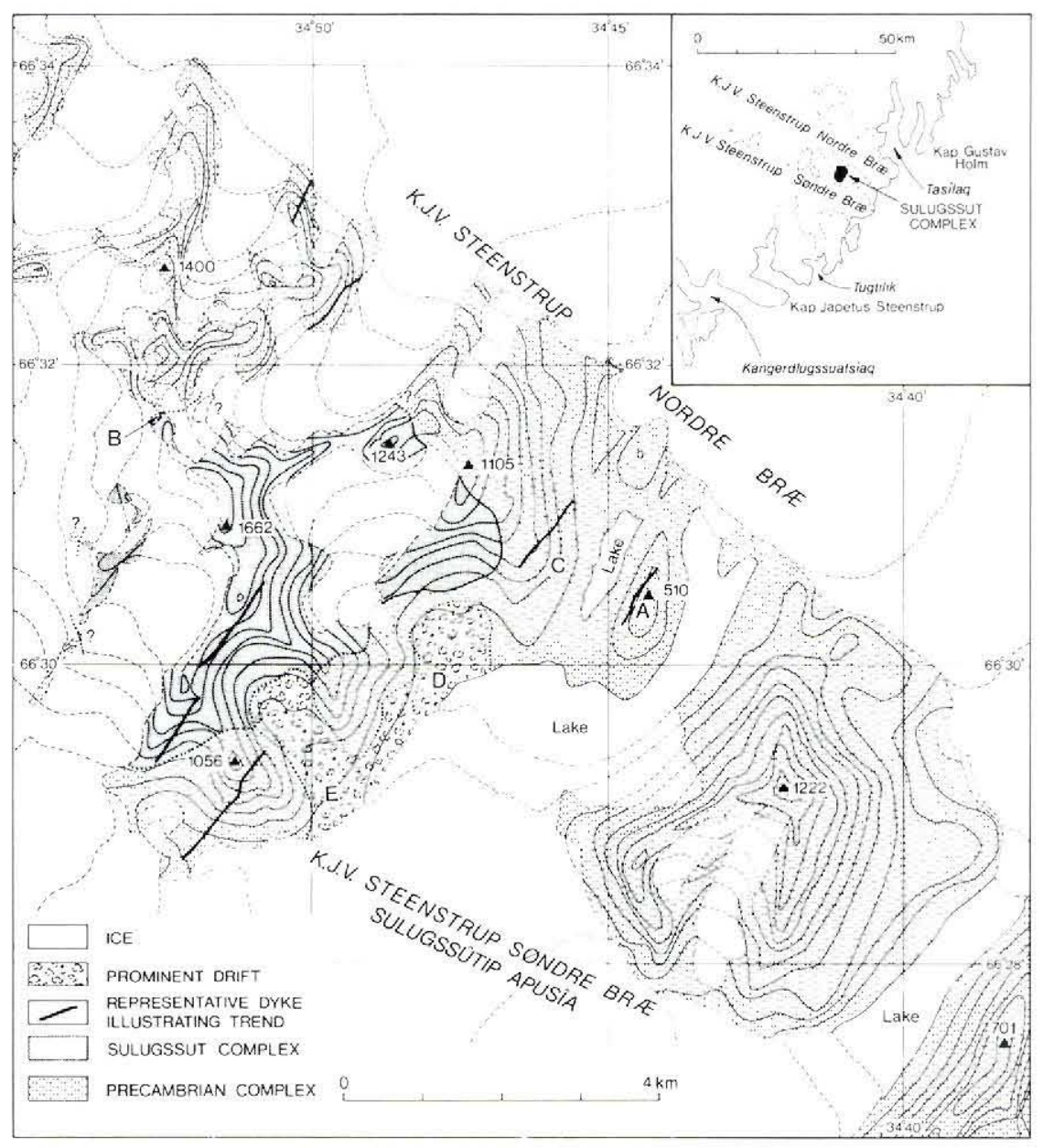

Fig. 1. Geological and topographical map of the Sulugssut intrusive complex, with general location in East Greenland. Localities visited in 1986 are lettered A to E. Topographical contours at $100 \mathrm{~m}$ intervals; spot heights determined photogrammetrically.

on aerial photographs. In the area north-east of peak $1243 \mathrm{~m}$ the trend of the contact is uncertain. Dykes trending NE-SW occur and plutonic rocks may also outcrop farther down the ridge towards K. J. V. Steenstrup Nordre Bræ. In the south-east and south, dense concentrations of dykes cutting both the plutonic core and the Precambrian gneisses, mask the boundary relations. The western boundary of the complex can only be determined with reference to several small nunataks, the composition of which is difficult to interpret from the available data.

No plutonic rocks or grey alkaline dykes were found on the north side of K. J. V. Steenstrup Nordre Bræ around Tasîlak, or in the terrain to the south. Thus it seems that the complex is of limited extent, being restricted to the semi-nunatak between the two glaciers.

According to the photo-interpretation, the plutonic core reaches $5 \mathrm{~km}$ in diameter. However, the lack of plutonic rocks in the float at locality $\mathrm{E}$ (see below) suggests that this may be an over-estimation.

\section{Lithologies}

As described above, the composition of the Sulugssut complex is known from samples collected at four localities.

Locality $A$, at altitude $480 \mathrm{~m}$, exposes a dyke swarm cutting amphibolite facies gneisses. The dykes are subparallel and generally trend $040^{\circ}$ and they vary from vertical to dipping $75^{\circ}$ to the north-west. Apart from the brown-weathering olivine dolerite dykes that reach up to $10 \mathrm{~m}$ thick, three other, rather thinner dyke types were noted.

Type 1. Grey porphyritic dykes having alkali feldspar and nepheline in a fine-grained groundmass.

Type 2. Greenish, fine-grained trachytic to phonolitic dykes (tinguaites).

Type 3. Rusty-brown weathering, fine-grained, darkcoloured porphyritic dykes.

Dykes of the three types range in thickness from less than $30 \mathrm{~cm}$ to a little over a metre. Types 1 and 3 were 
seen to cut and chill against the regional olivine dolerites of the coastal dyke swarm.

Locality $B$ at approximately $1460 \mathrm{~m}$ is located on a high, razor-sharp ridge which at this locality is primarily made up of a dense swarm of dykes of diverse types, some of which cut a dark pyroxene-nepheline rock (ijolite) that was not seen in dyke form and thus may well form the plutonic host rock at this locality. The dykes noted include green tinguaites of type 2 above, grey dykes probably of type 1 above, dark highly fissile rocks, grey microsyenites and a very felsic rock type remarkable for its schillerized feldspars ('moonstone'). At this locality it is difficult to determine the mutual relationships of these rocks due to the extensive frost shattering. However, a notable observation is that grey dykes are relatively young in the chronology cutting at least one generation of dark dykes, as well as the dark ijolite.

This locality is just south of the main, but inaccessible, contact of the plutonic core. Brecciation of the country rock gneisses by igneous rock has occurred with rotation of gneiss blocks.

Locality $C$ at about $440 \mathrm{~m}$, is on sloping terrain at the lower end of a traverse across a dyke swarm that cuts the Precambrian gneisses. The swarm is composed of relatively thin dykes (up to $1 \mathrm{~m}$ ) of numerous undersaturated evolved types, including phonolites and tinguaites. No olivine dolerite dykes of the regional type or mafic undersaturated types were encountered.

Locality $D$ is situated on a prominent moraine below a major cirque, where it was considered that a representative collection of the major rock types of the complex could be examined in the short time available. A suite of coarse-grained, plutonic rocks, varying from mafic pyroxenitic to felsic types was collected. In some of the larger blocks igneous layering was seen. However, igneous layering seems not to be a prominent feature of the complex: none was seen from the helicopter in the well-exposed cirque walls above this locality or elsewhere.

Locality $E$, on moraine below an eastern facing cirque was visited briefly. The moraine consists predominantly of gneisses and hypabyssal rocks; surprisingly no plutonic rocks were seen during the short stop.

\section{Age and affinities of the complex}

The complex, so far as can be discerned, consists of a rather mafic plutonic core cut by swarms of alkaline dykes which extend out into the country rock gneisses. We interpret the complex as the deeply eroded infrastructure of a nephelinitic volcano, similar perhaps to younger and better preserved examples in East Africa such as Napak (King, 1949).

The dykes cutting the complex include brown-weathering olivine dolerites that we associate with the main Tertiary coast-parallel swarm. If this is correct the plutonic core of the complex is of early Tertiary or older age. However, it should be noted that Mitchell (1978) from the area immediately south and west of Tugtilik has reported dolerite dykes that have given a variety of $\mathrm{K}$-Ar ages, including Cambrian, Jurassic, Cretaceous and Tertiary. The dykes dated show a range of trend and apparently show field relationships that indicate the presence of several generations. Although Mitchell (1978) argues strongly that his results are indicative of Palaeozoic, Mesozoic and Cenozoic magmatism, without further geochronological work the exact history of dyke injection in this region is unclear. Appraisal of the data reported by Mitchell (1978) suggests that in addition to definite Tertiary dykes, there may be some very old dykes (c. $550 \mathrm{Ma})$ although the intermediate 'ages' are suspect (A. Mussett, personal communication, 1987). It is tantalising, however, that a preliminary $\mathrm{K}$-Ar age determination on hornblende from a basic plutonic rock from the Sulugssut complex has given a value of $158 \mathrm{Ma}$ (P. M. Holm, personal communication, 1987). This late Jurassic age is not at variance with the local geology as described above but the only other suggested Jurassic magmatic event from East Greenland is the poorly-documented K-Ar age (164 $\pm 3-178$ $\pm 3 \mathrm{Ma}$ ) on a single dyke (trend $085^{\circ}$ ) west of Tugtilik reported on by Mitchell (1978). We conclude that the precise age of the Sulugssut complex must await a more detailed radiometric age study.

All the dykes seen cutting the complex trend generally between north and north-east, that is approximately parallel to the prominent coast-parallel regional swarm of brown-weathering olivine tholeiites (fig. 1). The main period of emplacement of the coastal dyke swarm was between 53 and 55 Ma (Beckinsale et al., 1970; Gleadow \& Brooks, 1979) that is at about the Palaeocene-Eocene boundary and in the reversed magnetic polarity epoch before anomaly 24 on the Hailwood et al. (1979) time scale. Both within the core and in the surrounding gneisses, the brown-weathering dykes are cut by the thinner alkaline dykes of the complex. We suggest therefore that the evolution of the volcano spanned the main period of emplacement of the coastal dyke swarm and coastal flexure (Nielsen \& Brooks, 1981). This accounts for the parallelism of the regional and local dykes - they were presumably emplaced in a similar stress field.

While awaiting further isotopic study we regard the Sulugssut complex to be of early Tertiary age belonging 


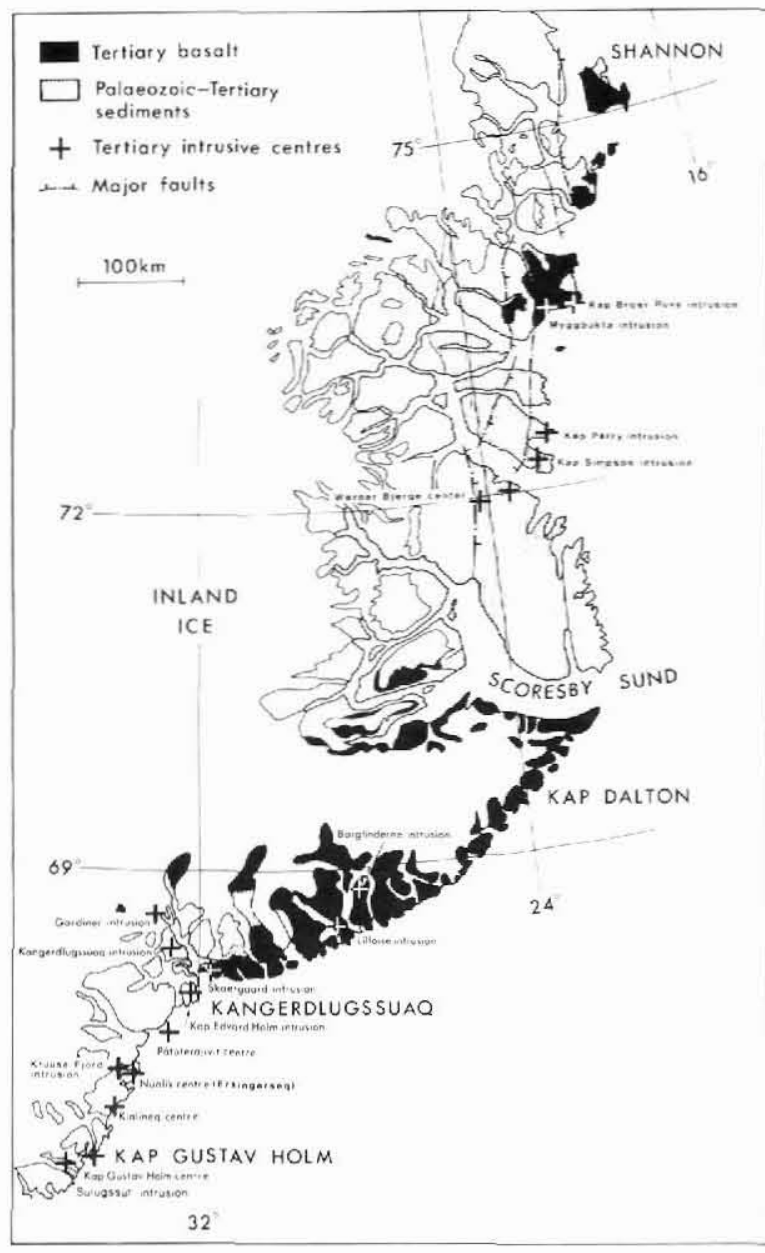

Fig. 2. General geological sketch map of East Greenland showing the main outcrops of Tertiary sediments and volcanics, as well as igneous intrusions. Location of the Sulugssut intrusion at the southern end of the Tertiary line is at about $66^{\circ} 30^{\prime} \mathrm{N}$.

to the well known suite of Tertiary centres which extends for more than $1000 \mathrm{~km}$ to the north along the East Greenland coast (fig. 2). It is the most southerly of these centres so far identified.

\section{Petrography}

Some fifty rock samples have been studied. These demonstrate that a wide variety of rock types, both plutonic and hypabyssal, exist and field observations indicate that there are many generations of dykes. However, the tripartite chronology: plutonic core, intruded by at least some of the regional dykes. intruded by local alkaline dykes, is put forward here with some confidence. It is assumed that the dykes represent equivalent magma types to those of the plutonic rocks, although it seems clear that they occur in very discrepant relative proportions.

In broad terms the samples fall into two main groups: a mafic group, broadly ijolites derived from a nephelinitic magma, and a felsic group composed of phonolites, tinguaites and nepheline syenites. The mafic group contains predominantly plutonic rocks, while phonolitic rocks are most abundant among the dykes. A coarsegrained plagioclase-rich rock lies outside this grouping. Out of the fifty samples sectioned only a few examples of this rock type occur and it is assumed to be of minor volumetric importance. Many samples, both mafic and felsic, contain sodalite but the precise distribution has not been investigated.

\section{Mafic rocks}

The mafic (largely plutonic) rocks consist of pale brownish clinopyroxene and nepheline, accompanied by lesser, but variable amounts of biotite, amphibole and opaque minerals with sphene and apatite as accessory phases. Sphene is present both as individual crystals and as thin rims on opaque oxides. A few samples contain perovskite, which again is associated with the oxides. Typical mafic plutonic rocks have crystals up to $1 \mathrm{~cm}$ in size and they show a range to leucocratic types largely by variation in the ratio of pyroxene to nepheline. The thoroughly mafic types are melteigites, the intermediate ones are ijolites (fig. 3) and the more leucocratic grade towards urtites.

A dark rock, strongly fissile in outcrop, and collected in situ only from one dyke at locality $\mathrm{B}$, is worthy of note. It is reminiscent of the black lujavrites of the Ilímaussaq intrusion in South Greenland (Ferguson, 1962 ), but in thin section it is made up largely of clino-

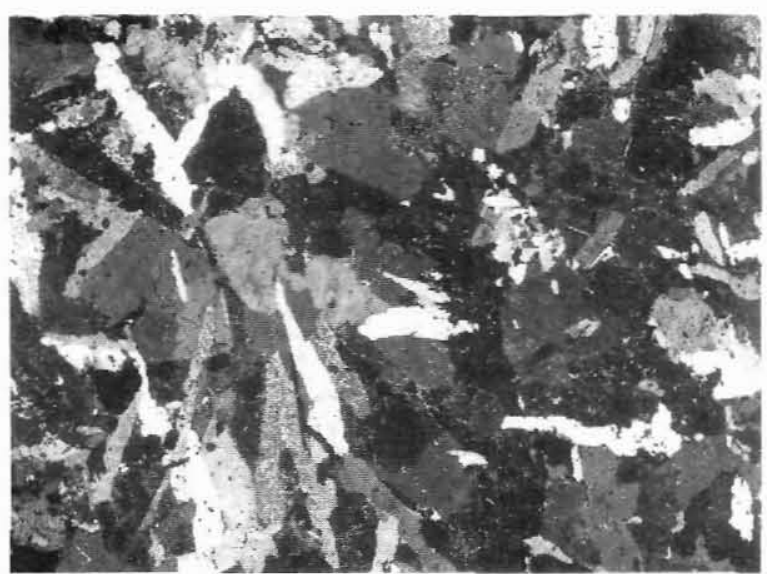

Fig. 3. Photomicrograph of a plutonic ijolite consisting largely of pyroxene and nepheline. Crossed nicols: field of view about $40 \mathrm{~mm}$ across. 


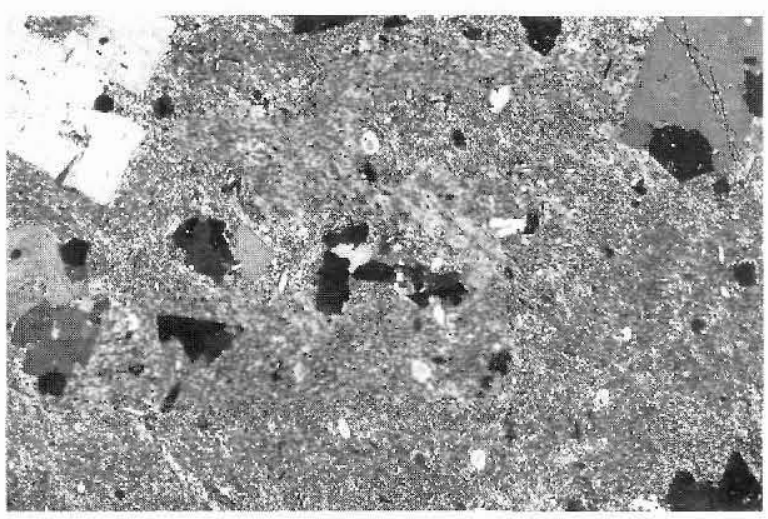

Fig. 4. Photomicrograph of phonolite dyke composed of finegrained groundmass largely of alkali feldspar enclosing euhedral nepheline phenocrysts. Nepheline shows shades of grey due to variable extinction. Crossed nicols; field of view about $40 \mathrm{~mm}$ across.

pyroxene, nepheline, biotite and opaque minerals with a granular texture. The fissility apparently arises from rapid variations in the modal proportions of these minerals. The oxides are rimmed with sphene. This rock type is the only fine-grained example of the mafic rock group and may represent a liquid composition.

Gabbroic rocks from locality D are alkali gabbros or essexites. A typical rock is composed largely of amphibole and plagioclase, which is up to $1 \mathrm{~cm}$ in size. The amphibole is pale brownish, zoning to greenish at the rims. Other minerals, in minor amounts, are nepheline, alkali feldspar, biotite, opaque minerals and accessory apatite. In common with the rocks described above, sphene forms rims on the oxides.

\section{Felsic rocks}

Phonolites are variable in the field ranging from grey, through green to dark green, probably reflecting the abundance of alkali pyroxene in the groundmass. Green varieties with nepheline and occasionally alkali feldspar phenocrysts conform to the term tinguaite, and of the dykes sampled, this appears by far to be the most important type. The rocks are coarsely porphyritic with thin, tabular alkali feldspars and nepheline phenocrysts up to $5 \mathrm{~mm}$. Whereas feldspar is trequently absent. nepheline is ubiquitous. It is euhedral and often occurs in aggregates (glomerocrysts). Clinopyroxene phenocrysts, up to $2 \mathrm{~mm}$ in size. are also ubiquitous. They are brownish in colour, probably salites, with rims of deep green aegirine-augite and sporadic overgrowths of dark green alkali amphibole. Brown amphibole phenocrysts are also common while sphene may occur as sparse phenocrysts of a similar size. The groundmass consists of very fine-grained felsic minerals (fig. 4) often showing a felted or trachytic texture, and needles of alkali pyroxene and/or alkali amphibole.

Plutonic equivalents of these dyke rocks are nepheline syenites; leucocratic, coarse-grained rocks with a pinkish, greasy lustre on fresh surfaces due to the abundance of nepheline. Alkali feldspar occurs in subordinate amounts while the mafic minerals are: alkali pyroxene, with a high aegirine content, alkali amphibole (arfvedsonite) and sphene. Sphene is relatively abundant and occurs in large honey-yellow crystals, readily visible to the naked eye. Nepheline syenites were recovered in situ at locality B. but their relationships with the other rocks could not be determined. Samples were also encountered in the float at locality D, but our general impression is that nepheline syenites are greatly subordinate in amount to the ijolites.

A remarkable dyke rock was sampled at locality B. This is very leucocratic with only about 1 per cent mafic minerals and most eye catching are schillerized alkali feldspars up to $5 \mathrm{~mm}$. The rock consists largely of nepheline and alkali feldspar with sparse pale green augite/ salite and opaque minerals. Although only about $1 \mathrm{~m}$ in width, the dyke is relatively coarse grained throughout, lacking the prominent porphyritic texture common to the other phonolites.

\section{Chemistry}

Chemical compositions for ten selected samples are presented in Table 1. All samples are very fresh as indicated by their low volatile contents and they conform to the patterns expected for ijolites and phonolites. Thus the mafic rocks have silica contents in the range 37 to 41 per cent and the felsic rocks 47 to 56 per cent; all have high alkali contents between 6 and 10 per cent, and 12 and 16 per cent respectively.

Normatively the mafic rocks are characterized by an abundance of ne, absence of or and $a b$ and the presence of $l c$. Di is a major constituent and minor $I n$ also occurs, reflecting the Ca-rich, undersaturated character of the parent magmas. All these features are characteristic of nephelinites and their intrusive equivalents, members of the ijolite family (Bailey, 1974).

The felsic rocks have $o r, a b$ and substantial quantities (30-40 per cent) of ne in the norm as is to be expected of phonolites. In addition, small amounts of normative $a c$ occur, reflecting a peralkaline character, which is a feature of rocks designated tinguaite. However, none are sufficiently peralkaline to contain the normative component $n s$. Variations in the relative proportions of the felsic phases are marked and may be due to a number of factors, for example crystal fractionation, or loss of a 
Table 1. Chemical analyses of rocks from the Sulugssut alkaline complex, East Greenland

\begin{tabular}{lrrrrrrrrrr}
\hline & 060 & 072 & 068 & 061 & 043 & 069 & 071 & 059 & 064 & 083 \\
\hline $\mathrm{SiO}_{2}$ & 37.78 & 38.61 & 39.48 & 41.00 & 47.61 & 47.96 & 48.75 & 53.05 & 56.11 & 56.30 \\
$\mathrm{TiO}_{2}$ & 2.96 & 2.47 & 2.52 & 2.14 & 1.26 & 0.90 & 1.56 & 0.66 & 0.28 & 0.27 \\
$\mathrm{Al}_{2} \mathrm{O}_{3}$ & 11.79 & 12.20 & 15.31 & 14.02 & 18.99 & 24.08 & 20.55 & 20.41 & 23.48 & 22.10 \\
$\mathrm{Fe}_{2} \mathrm{O}_{3}$ & 8.95 & 7.78 & 5.41 & 5.24 & 3.60 & 1.71 & 2.13 & 2.08 & 0.17 & 2.46 \\
$\mathrm{FeO}$ & 7.98 & 6.40 & 5.63 & 4.70 & 3.94 & 2.81 & 5.28 & 2.10 & 0.73 & 0.08 \\
$\mathrm{MnO}$ & 0.30 & 0.24 & 0.22 & 0.15 & 0.22 & 0.14 & 0.13 & 0.17 & 0.03 & 0.11 \\
$\mathrm{MgO}$ & 6.94 & 7.20 & 5.87 & 7.84 & 1.94 & 1.05 & 3.20 & 0.84 & 0.19 & 0.08 \\
$\mathrm{CaO}$ & 13.48 & 16.61 & 13.60 & 15.10 & 6.23 & 4.61 & 8.63 & 2.46 & 0.99 & 0.97 \\
$\mathrm{Na} 2$ & 4.79 & 3.82 & 5.74 & 4.82 & 9.02 & 10.11 & 5.48 & 10.04 & 8.43 & 10.35 \\
$\mathrm{~K}_{2} \mathrm{O}$ & 1.99 & 1.23 & 1.77 & 2.08 & 3.77 & 2.77 & 1.18 & 4.48 & 7.72 & 5.32 \\
$\mathrm{P}_{2} \mathrm{O}$ & 1.35 & 1.80 & 1.63 & 0.79 & 0.47 & 0.27 & 1.02 & 0.22 & 0.08 & 0.05 \\
$1.0 . i$. & 1.10 & 0.77 & 1.93 & 1.04 & 1.28 & 1.13 & 1.20 & 1.06 & 0.63 & 1.05 \\
& 99.21 & 99.13 & 99.11 & 98.92 & 98.33 & 97.54 & 99.11 & 98.57 & 98.84 & 99.14
\end{tabular}

C.I.P.W. weight norm

\begin{tabular}{lrrrrrrrrrr} 
or & - & - & - & - & 22.91 & 16.80 & 7.12 & 27.15 & 46.45 & 32.05 \\
ab & - & - & - & - & 10.70 & 17.54 & 33.91 & 24.46 & 18.02 & 31.19 \\
an & 4.88 & 12.72 & 11.09 & 10.70 & - & 12.46 & 28.59 & - & 3.49 & - \\
ne & 22.38 & 17.80 & 27.07 & 22.57 & 36.92 & 38.07 & 7.28 & 31.22 & 29.59 & 29.52 \\
Ic & 9.40 & 5.79 & 8.44 & 9.85 & - & - & - & - & - & - \\
ac & - & - & - & - & 1.20 & - & - & 4.44 & - & 3.16 \\
di & 35.69 & 39.35 & 35.18 & 34.59 & 16.37 & 7.75 & 6.82 & 8.05 & 0.82 & 0.44 \\
wo & - & - & - & - & 3.56 & - & - & 0.53 & - & 1.59 \\
ln & 2.85 & 2.80 & 0.87 & 5.07 & - & - & - & - & - & - \\
ol & 2.66 & 1.07 & 0.46 & 3.43 & - & 2.44 & 7.69 & - & 0.65 & - \\
mt & 13.23 & 11.47 & 8.07 & 7.76 & 4.76 & 2.54 & 3.15 & 2.35 & 0.25 & - \\
il & 5.73 & 4.77 & 4.92 & 4.15 & 2.46 & 1.75 & 3.03 & 1.29 & 0.54 & 0.41 \\
ap & 3.19 & 4.24 & 3.89 & 1.87 & 1.12 & 0.64 & 2.41 & 0.52 & 0.19 & 0.12 \\
& & & & & & & & & & \\
$\mathrm{Zr}$ & 100 & 126 & 95 & 108 & 172 & 27 & 67 & 269 & 66 & 268 \\
$\mathrm{Sr}$ & 696 & 743 & 1130 & 505 & 1261 & 5160 & 2330 & 1230 & 1360 & 111 \\
$\mathrm{Ba}$ & 1370 & 214 & 203 & 505 & 1630 & 6300 & 884 & 729 & 849 & 473 \\
$\mathrm{Cl}$ & 2070 & 490 & 680 & 400 & 650 & 390 & 250 & 900 & 30 & 2300 \\
$\mathrm{~S}$ & 3060 & 8370 & 450 & 3210 & 930 & 560 & 1620 & 330 & 1070 & 60 \\
\hline
\end{tabular}

312060: dark, fissile dyke.

312068: plutonic ijolite.

312043: phonolite dyke.

312071: plutonic alkali gabro.

312064: dyke - perthosite with schillerized feldspar.

312083: phonolite dyke

(norm has also: $1.41 \%$ he and $0.10 \% \mathrm{pf}$ ).
312072: plutonic ijolite

312061: mafic dyke.

312069: plutonic nepheline syenite.

312059: phonolite dyke. volatile phase. It would require the study of many more samples than has been carried out here to clarify the reasons for these variations.

Among the trace elements, exceptionally high concentrations of $\mathrm{Sr}$ and $\mathrm{Ba}$ are found in several rocks. On the other hand $\mathrm{Zr}$ is low: the nepheline syenite having only $27 \mathrm{ppm}$, which is only about one quarter of that commonly found in tholeiitic basalts. $\mathrm{Cl}$ and $\mathrm{S}$ tend to show elevated values, probably reflecting the incidence of minerals of the sodalite group and sulphides.

\section{Sulugssut and the East Greenland Tertiary Province}

Alkaline dykes (described as lamprophyres) occur at Tugtilik about $25 \mathrm{~km}$ to the south-west of Sulugssut (Rucklidge et al., 1980). These, like the Sulugssut alkaline dykes, are younger than the coastal dyke swarm. They include highly alkaline, mafic types of nephelinitic composition as well as less extreme basanitic types. Subsequent to the original description by Rucklidge $e t$ 
Table 2. Comparison of nephelinites from various parts of East Greenland

\begin{tabular}{lrrrr}
\hline & 060 & $20735 / \mathrm{C}$ & Gardiner & $901 \mathrm{~b}$ \\
\hline $\mathrm{SiO}_{2}$ & 37.78 & 39.55 & 37.16 & 38.30 \\
$\mathrm{TiO}_{2}$ & 2.96 & 2.69 & 5.69 & 4.70 \\
$\mathrm{Al}_{2} \mathrm{O}_{3}$ & 11.79 & 13.95 & 2.61 & 6.25 \\
$\mathrm{Fe}_{2} \mathrm{O}_{3}$ & 8.95 & 3.77 & 11.78 & 6.79 \\
$\mathrm{FeO}$ & 7.98 & 7.45 & 5.98 & 7.60 \\
$\mathrm{MnO}$ & 0.30 & - & - & 0.20 \\
$\mathrm{MgO}$ & 6.94 & 5.28 & 11.52 & 16.36 \\
$\mathrm{CaO}$ & 13.48 & 12.24 & 20.48 & 12.65 \\
$\mathrm{Na}_{2} \mathrm{O}$ & 4.79 & 6.38 & 3.00 & 2.48 \\
$\mathrm{~K}_{2} \mathrm{O}$ & 1.99 & 1.42 & 0.03 & 1.49 \\
$\mathrm{P}_{2} \mathrm{O}_{5}$ & 1.35 & 1.28 & 1.03 & 1.50 \\
l.o.i. & 1.10 & 4.38 & 1.39 & - \\
& 99.21 & 98.38 & 99.26 & 100.06
\end{tabular}

C.I.P.W. weight norm

\begin{tabular}{lrrrr} 
an & 4.88 & 5.52 & 0.25 & 1.51 \\
ne & 22.38 & 31.20 & 6.05 & 11.36 \\
lc & 9.40 & 7.02 & 1.48 & 6.91 \\
di & 35.69 & 38.99 & 53.60 & 39.25 \\
ol & 2.66 & 5.49 & 2.69 & 16.38 \\
ln & 2.85 & 0.94 & 7.98 & 0.71 \\
he & - & - & 9.86 & - \\
mt & 13.23 & 2.22 & 2.78 & 9.85 \\
il & 5.73 & 5.45 & 10.81 & 8.93 \\
ap & 3.19 & 3.17 & 2.39 & 3.12 \\
\hline
\end{tabular}

060: GGU 312060 quoted from Table 1.

20735/C: lamprophyre dyke, Tugtilik, quoted in Rucklidge et al. (1980).

Gardiner: ijolite ring dyke, Gardiner intrusion, quoted in Nielsen (1980, analysis 1 , table 8 ).

901b: olivine nephelinite plug in Alpedal, Strindberg Land $\left(74^{\circ} \mathrm{N}\right)$, quoted in Katz (1952).

al. other dykes, even more understaturated, have been found. These are rich in carbonate and are probably best termed silicocarbonatites. However, the relationship between these and the Sulugssut complex is unknown and petrographically there are no exact parallels.

The Sulugssut occurrence is the first record of in situ tinguaites in this part of East Greenland. Previously tinguaites have been reported by Bearth (1959) from the Werner Bjerge Complex (fig. 2). Tinguaites have also been found as erratic blocks in raised beaches and moraines at Kangerdlugssuaq about $250 \mathrm{~km}$ to the north (Brooks \& Rucklidge, 1974) where they are believed to originate from the poorly-explored nunatak region. In 1987 similar rocks were found as dykes in the marginal parts of the Kangerdlugssuaq alkaline intrusion.

Undersaturated igneous rocks are a marked feature of the East Greenland sector of the North Atlantic province (fig. 2), setting it apart from the Hebridean, Faeroese, Icelandic and West Greenlandic areas. Voluminous quartz syenites are widespread and these appear to have been formed from magmas which reacted extensively with the continental crust (e.g. Brooks \& Gill, 1982). Cafemic rocks of the nephelinite association also occur, having been reported from the inner nunatak zone at $74^{\circ} \mathrm{N}$ (Katz, 1952; Brooks et al., 1979), the Gardiner - Prinsen of Wales area at the head of Kangerdlugssuaq (Frisch \& Keusen, 1977; Nielsen, 1980, 1981) and in the south at Tugtilik (Rucklidge et al., 1980) (figs $1 \& 2$ ). Of these, the only nephelinitic plutonic rocks occur in the Gardiner complex. The geographically nearest nephelinitic rocks to Sulugssut are the dykes at Tugtilik, which is only about $25 \mathrm{~km}$ distant and these

Table 3. Comparison of phonolites (tinguaites) from East Greenland

\begin{tabular}{lrrr}
\hline & 059 & 20725 & 29956 \\
\hline $\mathrm{SiO}_{2}$ & 53.05 & 54.43 & 54.30 \\
$\mathrm{TiO}_{2}$ & 0.66 & 1.05 & 2.11 \\
$\mathrm{Al}_{2} \mathrm{O}_{3}$ & 20.41 & 17.48 & 17.35 \\
$\mathrm{Fe}_{2} \mathrm{O}_{3}$ & 2.08 & 4.82 & 2.81 \\
$\mathrm{FeO}$ & 2.10 & 1.10 & 1.77 \\
$\mathrm{MnO}$ & 0.17 & 0.17 & 0.00 \\
$\mathrm{MgO}$ & 0.84 & 1.00 & 1.86 \\
$\mathrm{CaO}$ & 2.46 & 1.94 & 2.99 \\
$\mathrm{Na} 2 \mathrm{O}$ & 10.04 & 9.06 & 9.26 \\
$\mathrm{~K}_{2} \mathrm{O}$ & 4.48 & 5.37 & 3.26 \\
$\mathrm{P}_{2} \mathrm{O}_{5}$ & 0.22 & 0.16 & 0.30 \\
$1.0 . i$. & 1.06 & 3.08 & 0.74 \\
& 98.57 & 99.66 & 97.17
\end{tabular}

\section{C.I.P.W. weight norm}

\begin{tabular}{lccc} 
or & 27.15 & 31.74 & 19.27 \\
ab & 24.46 & 19.98 & 34.29 \\
ne & 31.22 & 21.69 & 19.94 \\
ac & 4.44 & 13.95 & 8.13 \\
ns & - & 0.19 & 0.39 \\
wo & 0.53 & - & - \\
di & 8.05 & 6.50 & 9.64 \\
ol & - & - & 0.11 \\
mt & 2.35 & - & - \\
il & 1.29 & 1.99 & 3.74 \\
ap & 0.52 & 0.37 & 0.70 \\
& & & \\
$\mathrm{Zr}$ & 269 & 1150 & 640 \\
$\mathrm{Sr}$ & 1230 & 1030 & 10000 \\
$\mathrm{Ba}$ & 729 & 560 & 3900 \\
\hline
\end{tabular}

059: GGU 312059 quoted from Table 1.

20725: sample MM 20725 from Brooks \& Rucklidge (1974, table 1).

29956: micronepheline syenite dyke, Gardiner intrusion. From Nielsen (1979, analysis 7, table 1). Norm has $0.24 \%$ pf. 
may well be connected to the volcanic centre described here. In addition, a nephelinitic tuff interlayered with the plateau basalts is reported from Scoresby Sund by Larsen \& Watt (1985). Nephelinites are of considerable interest, not least, because they appear to be uncontaminated mantle melts (Nielsen \& Buchardt, 1985).

While there are general similarities between the nephelinites (and their intrusive equivalents, ijolites) from all these areas (Table 2), the Sulugssut-Tugtilik samples show notable differences from the others. In particular, $\mathrm{TiO}_{2}$ is much lower, typically in the range $1-3$ per cent, as against 5-7 per cent, while $\mathrm{Al}_{2} \mathrm{O}_{3}$ is higher, i. e. 12-13 per cent compared to 3-8 per cent. Similar differences appear to exist with respect to the trace elements, but insufficient data is available for a meaningful comparison.

Phonolites (or tinguaites) are compared in Table 3. Again general similarities are apparent although these rocks form too variable a group for a detailed comparison with the small number of samples available from Sulugssut. However, it is probably significant that once again $\mathrm{TiO}_{2}$ is significantly lower while $\mathrm{Al}_{2} \mathrm{O}_{3}$ is higher than in the Kangerdlugssuaq samples. Likewise, $\mathrm{Zr}$ is low.

Evidence from the Gardiner complex (fig. 2; T. F. D. Nielsen, personal communication, 1986) shows that the phonolites can readily be derived from nephelinitic liquids by crystal fractionation and liquid immiscibility. It is assumed that similar processes operated at Sulugssut.

\section{Conclusions}

The Sulugssut intrusive complex is the exposed root of an assumed Tertiary nephelinitic volcano lying south of the previously known plutonic centres in East Greenland. It was formed from nephelinitic magmas that underwent an evolution to phonolites and it appears to have a complicated structure. Such associations are unknown in other areas of the North Atlantic province, but are described from other parts of East Greenland.

In general, such rocks are interpreted as products of very limited degrees of partial melting deep in the mantle. In East Greenland, their occurrence in inland regions was hitherto thought to indicate that such magma generation was restricted to distal parts of the protoIcelandic mantle plume (e.g. Brooks, 1985). The Sulugssut-Tugtilik rocks differ from other areas of nephelinitic magmatism in that they occur within $10 \mathrm{~km}$ of the coast and thus close to the locus of seafloor spreading during the early stages of formation of the North Atlantic Ocean (Larsen, 1984). These rocks also show certain chemical differences from the inland occurrences of nephelinites, the significance of which is at present obscure.

It seems clear that the discovery of the Sulugssut complex will necessitate a re-appraisal of the role of nephelinites in the tectonic evolution of the East Greenland continental margin. Possibly the location at the extreme southern end of the igneous province is significant. 